\title{
Quiet conversations
}

\section{Migraine, stroke, and dementia}

Jonathan H. Smith, MD

Neurology ${ }^{\circledR}$ 2019;93:167. doi:10.1212/WNL.0000000000007826

\section{Alone with a captor}

If you move, it will cut you.

If you cry, they won't believe you.

You are not welcome in this place.

This forbidden earth,

where sun and sound guard the gates.

\section{Correspondence}

Dr. Smith

smith.jonathan@mayo.edu

\section{MORE ONLINE}

\section{ค Audio}

Listen to Dr. Smith read these poems.

NPub.org/2dxw2w

\section{Alone with a machine}

Rocking by the bed

The demon hums

A white tight

Tug of tongues

One hand flaccid

The other numb

Twisted ties

Tubing crossed

Unheard thoughts

While the demon rocks

\section{Alone with a shell}

Beneath her eyelids

Shadows crawl like basement mold

The caves of old age 


\section{Neurology}

\section{Quiet conversations: Migraine, stroke, and dementia Jonathan H. Smith \\ Neurology 2019;93;167 \\ DOI 10.1212/WNL.0000000000007826}

This information is current as of July 22, 2019

$\begin{array}{ll}\begin{array}{l}\text { Updated Information \& } \\ \text { Services }\end{array} & \begin{array}{l}\text { including high resolution figures, can be found at: } \\ \text { http://n.neurology.org/content/93/4/167.full }\end{array} \\ \text { Permissions \& Licensing } & \begin{array}{l}\text { Information about reproducing this article in parts (figures,tables) or in } \\ \text { its entirety can be found online at: } \\ \text { http://www.neurology.org/about/about_the_journal\#permissions }\end{array} \\ \text { Reprints } & \begin{array}{l}\text { Information about ordering reprints can be found online: } \\ \text { http://n.neurology.org/subscribers/advertise }\end{array}\end{array}$

Neurology ${ }^{\circledR}$ is the official journal of the American Academy of Neurology. Published continuously since 1951, it is now a weekly with 48 issues per year. Copyright (O 2019 American Academy of Neurology. All rights reserved. Print ISSN: 0028-3878. Online ISSN: 1526-632X.

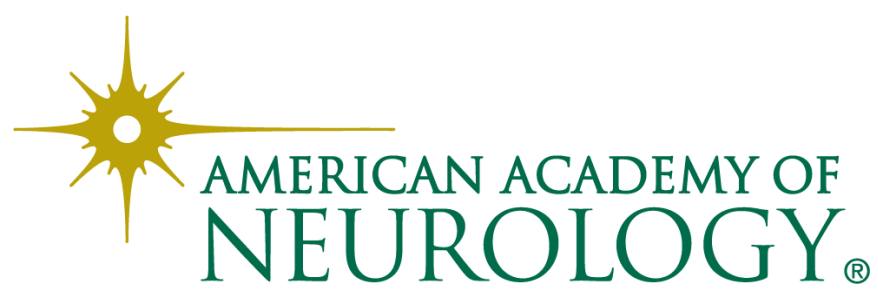

